\title{
GEOLOGY
}

UDC [552.574:552.16]:539.25

\author{
K.A. Bezruchko, Dr. Sc. (Geol.), Senior Research \\ Fellow, \\ orcid.org/0000-0002-3818-5624, \\ L. I. Pymonenko, Dr. Sc. (Geol.), Senior Research \\ Fellow, \\ orcid.org/0000-0002-5598-6722, \\ O. K. Balalaiev, Cand. Sc. (Biol.), Senior Research \\ Fellow, \\ orcid.org/0000-0002-9389-4562, \\ V. I. Baranovskyi, \\ orcid.org/0000-0002-0409-5292
}

DOI: $10.29202 /$ nvngu/2019-3/1

Institute of Geotechnical Mechanics named by N. Polyakov of National Academy of Sciences of Ukraine, Dnipro, Ukraine, e-mail: gvrvg@meta.ua

\section{A NEW DETERMINATION METHOD FOR COAL METAMORPHISM DEGREE}

Purpose. Development and approbation of a new method for determining the degree of coal metamorphism by the index of gray shade intensity of macerals for microphotographs of lump sections of coal samples.

Methodology. Optical spectroscopy using a video-optical complex: MBI - 11, HB 200, followed by digital computer processing (Scope photo software) of microphotographs of coal substance samples upon lump sections.

Findings. A new method is proposed for determining the degree of coal substance metamorphism, the essence of which is the use of optical microscopy of lump sections of coal samples, followed by digital processing of the obtained data. The method was tested on coal samples of various ranks - from long-flame to anthracite. To characterize the degree of coal metamorphism, a new index of the gray shade intensity of macerals was applied on the photographic images of the lump sections of coal samples microscopically. Correlation of the proposed index with the classical ones of the degree of coal metamorphism - vitrinite reflectance is shown.

Originality. For the first time, a digital processing of photographic images of the lump sections of coal samples using a new index of gray shade intensity of macerals was applied to characterize the degree of coal metamorphism.

Practical value. The proposed method can be used for practical application in order to assess the degree of coal metamorphism. This method differs by its operability and simplicity from the currently widely used one for determining the degree of coal metamorphism by vitrinite reflectance. The method can also be applied to assess the recoverability of coals and calculation of their maceral composition.

Keywords: coal, metamorphism, optical microscopy, gray shade intensity of macerals

Introduction. After transformation of peat into coal, during the post-diagenetic changes of the coal-bearing strata under the influence of geological factors (mainly temperature and pressure), the organic substance is further transformed. This irreversible process of consistently increasing carbon content by changing the chemical composition, physical properties and internal structure of carbofossils is called metamorphism. In the domestic and foreign literature along with this term, other terms are used - catagenesis, coalification, thermal maturity of coals. In this paper we use the term metamorphism, as the most recognized by researchers around the world in the field of coal geology and in ac-

(C) Bezruchko K.A., Pymonenko L.I., Balalaiev O.K., Baranovskyi V. I., 2019 cordance with modern international standards - USA Standard [1], International Standards [2], Ukraine Standard [3]. Thus, in the American Society for Testing and Materials (ASTM D388-18 Standard Classification of Coals by Rank), brought into use in 2018, it is noted: "This standard covers the classification of coals by rank, that is, according to their degree of metamorphism, or progressive alteration, in the natural series from lignite to anthracite" [1]. Indexes of metamorphism are the basis of coal classifications in most countries. Coal classification is necessary to assess the quality of coal, choose the possible and most rational directions and technologies for their use.

None of the physical, chemical, technological or structural indexes of coal varies in a strictly rectilinear manner. 
The factors which are closest to this tendency are vitrinite reflectance $\left(R^{0}\right)$, volatile-matter yield $\left(V^{\text {daf }}\right)$ and carbon content ( $\left.C^{d a f}\right)$. Given that the volatile-matter yield and carbon content substantially depend on the petrographic composition, the reflectance measured by one maceral is the only reliable index of the degree of coal metamorphism. However, this index is not perfect. In paper [4] it is noted how during the improvement of the standard [5] six samples of coal, representing the entire range of coal metamorphism, were provided by 22 laboratories in 14 countries of the world to measure the vitrinite reflectance $\left(R^{0}\right)$. As a result, the measurement error in one laboratory reached $0.03-$ $0.11 \%$, and in various laboratories it was $0.12-0.54 \%$. These are significant discrepancies, given that the entire range of $R^{0}$ values in the series of coal metamorphism is about $2 \%: 0.4 \%$ for long-flame and $2.5 \%$ for T-rank [3]. Along with obvious technical reasons for such discrepancies (optical characteristics of the microscope and photometer, room illumination, indicators of utility-supplied voltage, freshness of immersion oil, choice of a sample, a degree of polishing), the important aspect is the surface area from which vitrinite reflectance values are taken. According to regulatory documents, it is equal to approximately $80 \mu \mathrm{m}^{2}$; on the most frequently POOS- 1 instrument used for this purpose, the diameter of the light spot reaches $20 \mu \mathrm{m}$. Fig. 1 shows a fragment of the surface of the vitrinite for the coal bed of $k_{8}$ of the "Kurakhivska" mine. SE "Selydivvuhillia" with a size of $80 \mu \mathrm{m}^{2}$, which on the POOS-1 can look like a homogeneous one, without having been classified as such.

The reflectivity in this case in addition to the properties of the vitrinite substance depends on the characteristics of the sample surface and the result of the gel coagulation, formed by differently reclaimed fragments of the original plant material. Concerning the importance for choosing the object of the research in terms of the recoverability of coal (coal "recoverabilited" is a conditional term for designating among the isometamorphic coals of one basin with the same content of groups of microcomponents of those differences that are characterized by increased hydrogen content, in- creased volatile-matter yield and semi-coking resin, better solubility in organic solvents and better sintering; low oxygen content, reflectivity, refractive index. This concept originated in the Donets Basin, where differences in the chemical properties of isometamorphic clarain coals were established, and are increasingly referred to in coal geology research [6]. Considering the above in the trend of modern world tendencies of optical research (digital computer processing of microphotographs), we have proposed a new way to assess metamorphism, recoverability and petrographic composition of coal.

Methods. With the help of the video-optical complex: MBI - 11, HB 200 (Scope photo software [7]), micrographs of the surface of coal samples - particulate block, lump sections and natural shears (Micrographs) are made by PC (Fig. 2). The image size is $283 \times 213 \mathrm{mi}-$ crons (lens $20^{x}$; transition lens 1.6; hardware magnification HB 200).

Since samples of coal of different ranks have different reflectivity, and the photographs should be distinct and made with the same hardware settings, the following values were selected experimentally for Scope photoprogram: Exposure-48\3488; White balance - avto; Color - white \black; Gamma - 0.28; Satur - 42; Contrast -97 .

All further research is carried out by digital processing of the obtained microphotographs in specialized computer software.

The use of a particular type of a sample is due to its features and the tasks facing the research:

1. "Particulate block" is the most difficult sample in producing, the channel sample is crushed to a size of $<1 \mathrm{~mm}$, mixed with shellac it is heated to $>90^{\circ} \mathrm{C}$, which undoubtedly affects the optical properties of macerals and occurrence of technological cracks; particles come in sight both from the floor and the roof part of the bed section, the difference in the accumulation periods of which can reach thousands of years; the dimensional orientation of the particles in this sample may be random, which given the certain anisotropy of the optical properties of vitrinite, due to uniaxial compression, does not allow one to draw any

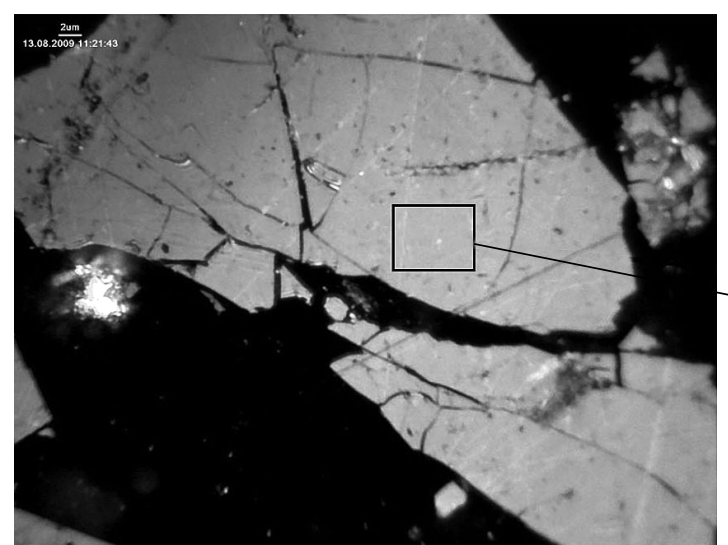

$a$

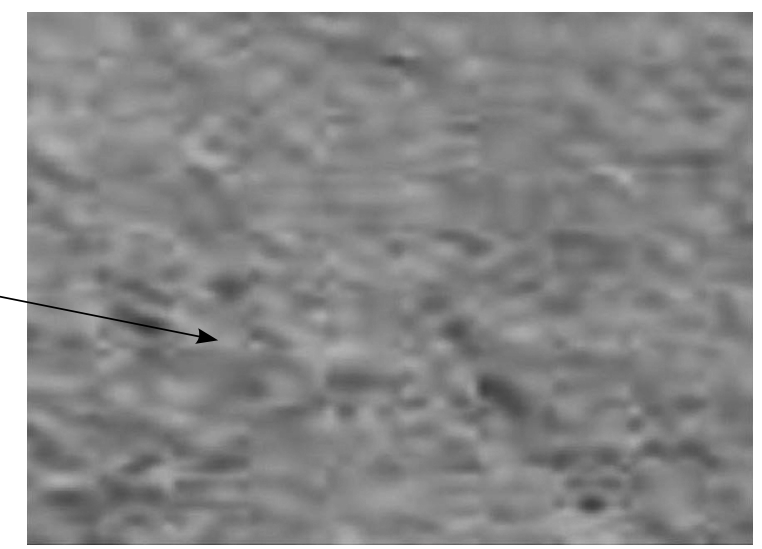

$b$

Fig. 1. Heterogeneity of the vitrinite surface on the surface area of the sample, by which the reflectivity is measured: $a-a$ site for recording the vitrinite reflectance value on the POOS-linstrument; $b$ - the same site at greater magnification 


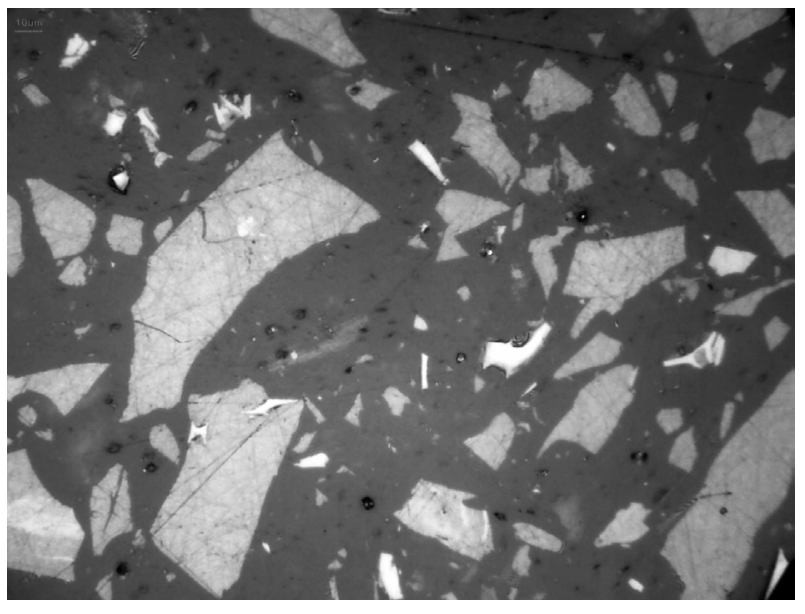

$a$

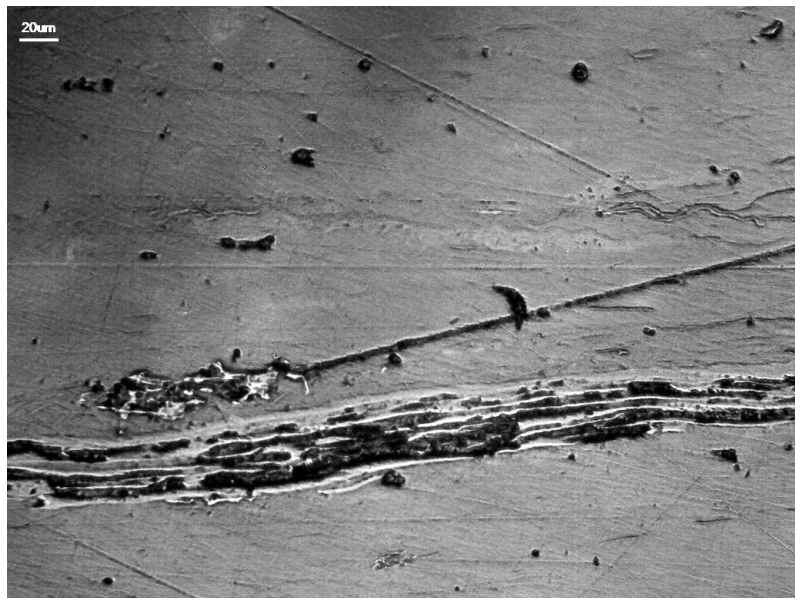

$b$

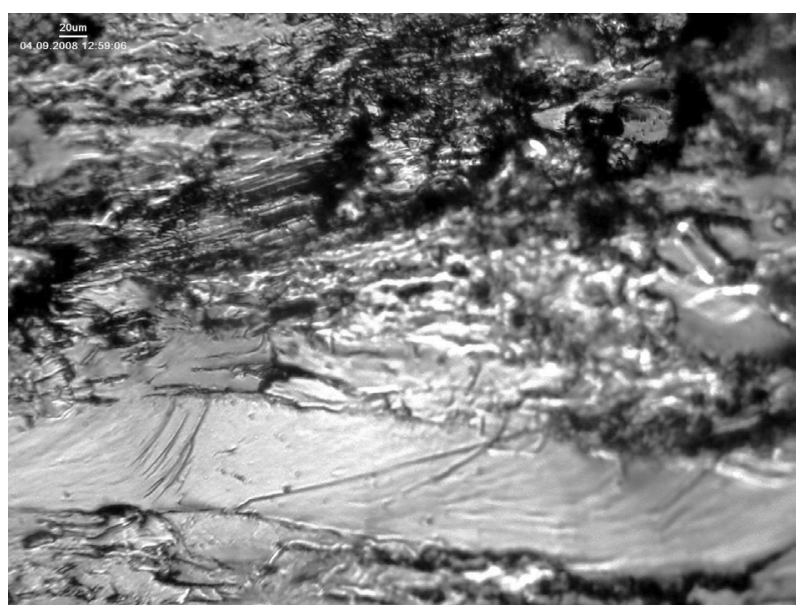

$c$

Fig. 2. Samples of coal:

$a$ - "particulate block"; $b$ - "lump section"; $c$ - "shear"

genetic conclusions. This sample can be used for gross calculation of the percentage of macerals for coke chemistry.

2. "Shear" does not require producing, but macerals are not distinguishable on it; it can be used for a preliminary assessment of the vitrinite reflectance (metamorphism), since natural shears in most cases are formed by cleavage in a gelled substance; for assessing the heterogeneity of vitrinite (recoverability) and, as it was shown by previous research [8], is the only sample for assessing gas showing in coals.

3. "Lump section" is the most universal sample for assessing the evolution of the structure of a coal substance in the process of metamorphism and he-terogeneity of vitrinite, as an index of recoverability; it is made by polishing of two mutually perpendicular planes (bedding and section) of a piece of coal of an arbitrary size.

In current research preference was given to "lump section" samples.

In the plane of the bedding of this sample there are microcomponents that have accumulated in the same period of time, which makes it possible to evaluate the effect of metamorphism on even-aged individual ingredients of petrographic coal composition, the heterogeneity of vitrinite and the correct difference in the reflectivity of different macerals.

For approbation of the proposed method, samples of various coal ranks of Donbas and Lviv-Volyn basin were analyzed [9]. 26 coal beds from 22 mines were tested.

From the two surfaces - lump sections of each sample (bedding and section) 10 micrographs were obtained. Each micrograph was imported into the Jmicrovision software [10] (Fig. 3).

This software allows one to analyze the gray shade intensity of macerals - ICM (range of changes 0-255, in contrast to $0.5-2.5 \%$ when measuring $\mathrm{R}^{0}$ ). This index (ICM) is proposed to replace the reflectivity one. Its values can be taken from a certain area (Fig. 3) and in the same software it is possible to conduct statistical processing of data. The obtained values of standard deviation (Std deviation), skewness, kurtosis, entropy characterize the heterogeneity of macerals (shown in the Fig. 3 - fusinite). The mean gray shade intensity in vitrinite is an index of the degree of metamorphism.

It is advisable to obtain the values of ICM index not as a mean value on any area, but as a single value at a point. In this case, the statistics data obtained in the software are not represented by a histogram, but by a straight vertical line with a single value of the index on the $x$-axis (Fig. 4).

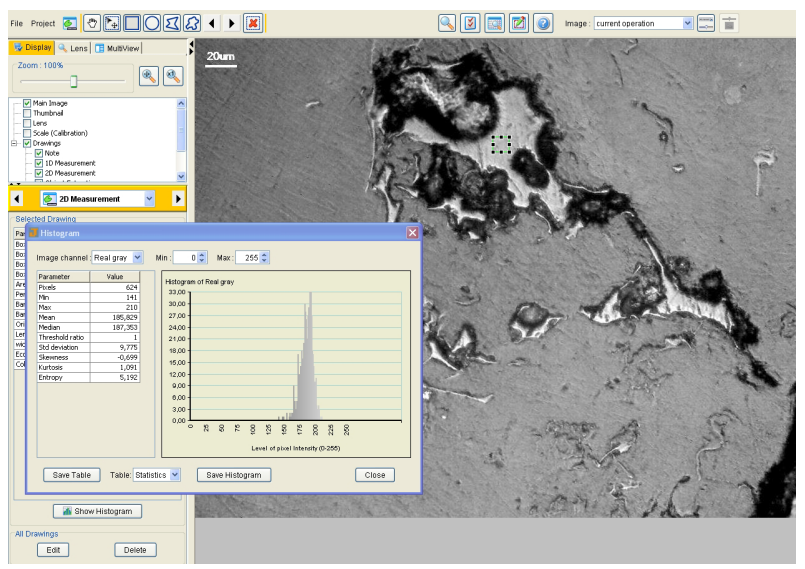

Fig. 3. Micrograph of the surface of bedding "lump section" in the Jmicrovision software 


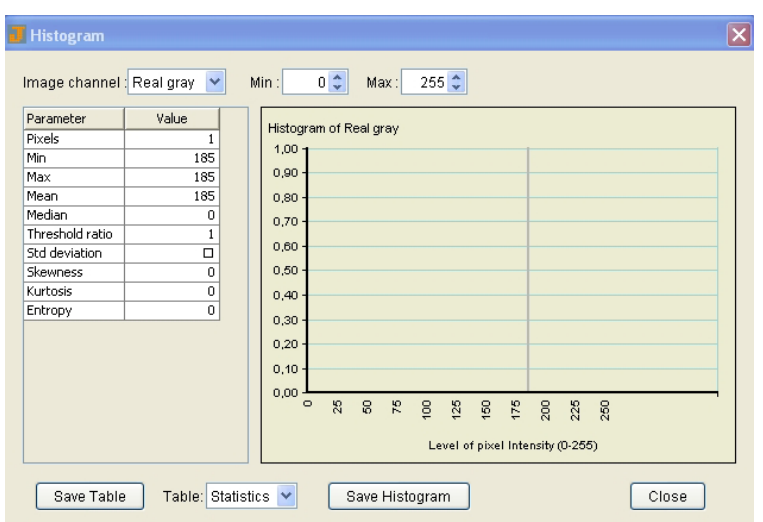

Fig. 4. The pointwise gray shade intensity of macerals in the Jmicrovision software

The Jmicrovision software in this case takes values from one pixel, and one pixel is by definition colored in one color (in this case there is a shade of gray).

The pointwise value of ICM is free from the influence of heterogeneity of macerals unlike $R^{0}$ and ICM mean and solves exactly the task that is set for it.

In case of taking of values from any area, a micrograph of this area is transmitted to the Image J software [11] to calculate the fractal dimension of the ICM values (Fig. 5).

In the research of samples in a series of metamorphism upon the lump sections of each mine bed, both in terms of bedding and across 10 micrographs were made. From each micrograph 10 values of indexes characterizing the degree of metamorphism and recoverability were taken (P. ICM - pointwise values of gray shade intensity of macerals; ICM. mean - the mean intensity of the shade of gray; St - standard deviation; $\mathrm{S}$ - skewness; $\mathrm{K}$ - kurtosis; $\mathrm{E}$ - entropy; $\mathrm{F}-$ fractal dimension of heterogeneity). Mean values of these indexes for each rank are shown in Table.

As it can be seen from the Table, the values of gray shade intensity of macerals in a series of metamorphism are similar to the known values of vitrinite reflectance. Graphically this is shown in Fig. 6.

The ICM values in the series of metamorphism grow for all microcomponents. In vitrinite and liptinite they are aligned in the area of OS-T ranks, in vitrinite and fuzinite - in anthracite.

As for the other indexes, given in Table, the following should be noted:

1. The ICM index in the area (ICM.mean), although insignificantly, is always greater than the similar one recorded at the point (P.ICM).

2. The ICM index by layering is always less than analogous one in the section.

3. Macerals of the liptinit group have the greatest heterogeneity.

4. There is a tendency for the heterogeneity of the gelified substance to decrease with increasing the degree of metamorphism.

The Jmicrovision software also allows calculating the petrographic composition of coals (Fig. 7).

It is better to carry out these calculations on particulate blocks and to improve the quality of the image in any graphic editor in advance.

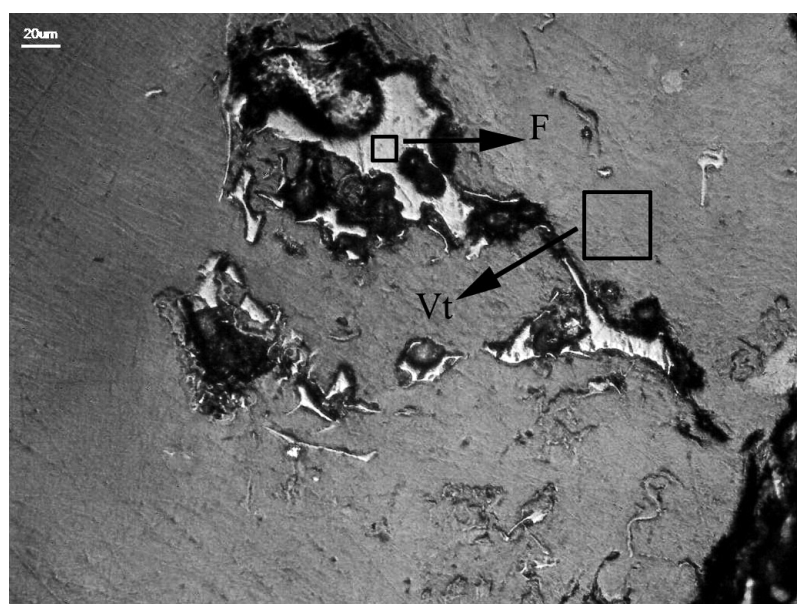

$a$
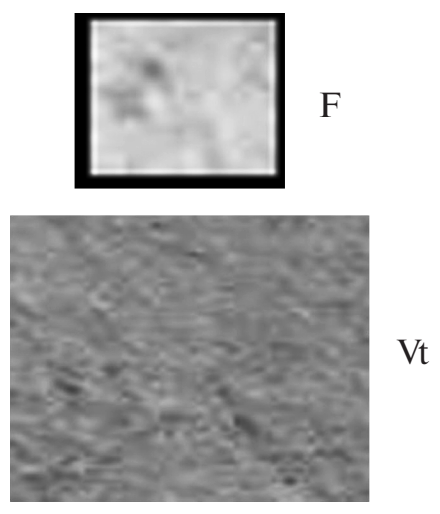

$b$

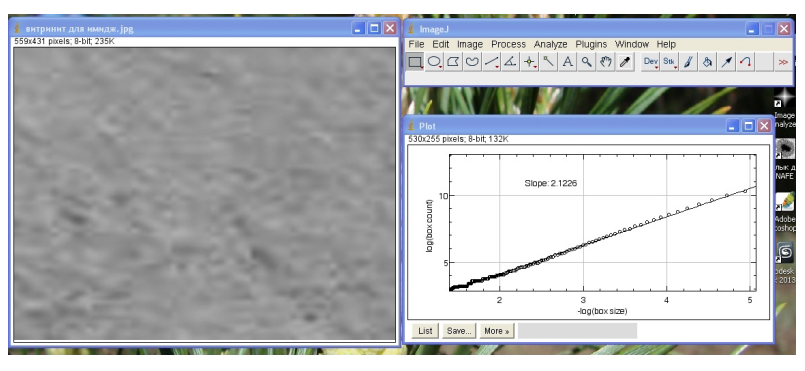

$c$

Fig. 5. Transferring images from Jmicrovision software to ImageJ one:

$a$ - an area of taking the ICM values in the Jmicrovision software; $b$ - micrographs of these sections; $c$ - processing of these micrographs in the ImageJ software

In a large number of editors among the foreign researchers recently, editors have been popular with micrographs based on fractal analysis. We used for this purpose a program developed by Miloslav Dracmüller at the Institute of Mathematics of the Czech Republic, which is called NAFE [12].

Conclusions. New methods of digital processing of micrographs of the surface of coal samples (lump section, particulate blocks, natural shear) showed:

- reliable correlation of the index of gray shade intensity of macerals (range of values $0-255$ ) with the classic indicators of the $R^{0}$ metamorphism (range $0.5-$ $2.5 \%)$; 
Table

Mean values of metamorphism and recoverability of coals in Donbas and Lviv-Volyn basins

\begin{tabular}{|c|c|c|c|c|c|c|c|c|c|}
\hline \multirow{2}{*}{$\begin{array}{l}\text { Coal } \\
\text { rank }\end{array}$} & \multirow{2}{*}{$\begin{array}{l}\text { Surface of } \\
\text { a sample }\end{array}$} & \multirow{2}{*}{ Maceral } & \multicolumn{2}{|c|}{ Metamorphism } & \multicolumn{5}{|c|}{ Recoverability } \\
\hline & & & P. ICM & ICM. mean & St & S & $\mathrm{K}$ & $\mathrm{E}$ & $\mathrm{F}$ \\
\hline \multirow[t]{6}{*}{ DG } & \multirow[t]{3}{*}{ bedding } & $\mathrm{Vt}$ & 138 & 139 & 6.46 & 0.19 & 0.02 & 4.71 & 2.12 \\
\hline & & $\mathrm{F}(\mathrm{I})$ & 181 & 183 & 7.55 & 0.43 & 1.16 & 4.81 & 2.04 \\
\hline & & $\mathrm{L}$ & 123 & 125 & 11.5 & 0.61 & 1.65 & 5.39 & 2.01 \\
\hline & \multirow[t]{3}{*}{ section } & $\mathrm{Vt}$ & 146 & 149 & 4.02 & 0.21 & 0.76 & 4.02 & 2.10 \\
\hline & & $\mathrm{F}(\mathrm{I})$ & 171 & 172 & 8.45 & 0.50 & 0.89 & 4.99 & 2.03 \\
\hline & & $\mathrm{L}$ & 123 & 123 & 5.42 & 0.83 & 0.55 & 4.21 & 2.00 \\
\hline \multirow[t]{6}{*}{ G } & \multirow[t]{3}{*}{ bedding } & $\mathrm{Vt}$ & 144 & 145 & 6.35 & 0.20 & 0.02 & 4.26 & 2.11 \\
\hline & & $\mathrm{F}(\mathrm{I})$ & 190 & 191 & 6.32 & 0.46 & 1.20 & 4.72 & 2.05 \\
\hline & & $\mathrm{L}$ & 130 & 131 & 10.2 & 0.72 & 1.78 & 5.08 & 2.02 \\
\hline & \multirow[t]{3}{*}{ section } & $\mathrm{Vt}$ & 146 & 148 & 5.03 & 0.25 & 0.03 & 4.26 & 2.09 \\
\hline & & $\mathrm{F}(\mathrm{I})$ & 192 & 193 & 8.60 & 0.56 & 1.24 & 4.88 & 2.04 \\
\hline & & $\mathrm{L}$ & 125 & 126 & 5.63 & 0.81 & 1.95 & 5.12 & 2.01 \\
\hline \multirow[t]{6}{*}{$\mathrm{ZH}$} & \multirow[t]{3}{*}{ bedding } & $\mathrm{Vt}$ & 151 & 160 & 5.07 & 0.18 & 0.15 & 4.34 & 2.16 \\
\hline & & $\mathrm{F}(\mathrm{I})$ & 196 & 215 & 10.3 & 0.35 & 0.38 & 5.31 & 2.06 \\
\hline & & $\mathrm{L}$ & 130 & 157 & 9.87 & 1.38 & 4.91 & 5.01 & 2.03 \\
\hline & \multirow[t]{3}{*}{ section } & $\mathrm{Vt}$ & 169 & 170 & 4.69 & 0.23 & 0.44 & 4.18 & 2.14 \\
\hline & & $\mathrm{F}(\mathrm{I})$ & 224 & 214 & 10.41 & 0.16 & 0.32 & 5.06 & 2.05 \\
\hline & & $\mathrm{L}$ & 149 & 147 & 8.04 & 0.25 & 0.78 & 4.37 & 2.05 \\
\hline \multirow[t]{6}{*}{ K } & \multirow[t]{3}{*}{ bedding } & $\mathrm{Vt}$ & 178 & 179 & 5.06 & 0.19 & 0.21 & 4.36 & 2.17 \\
\hline & & $\mathrm{F}(\mathrm{I})$ & 199 & 200 & 9.45 & 0.40 & 0.44 & 5.38 & 2.07 \\
\hline & & $\mathrm{L}$ & 145 & 145 & 8.88 & 1.42 & 1.26 & 5.88 & 2.03 \\
\hline & \multirow[t]{3}{*}{ section } & $\mathrm{Vt}$ & 179 & 180 & 4.80 & 0.21 & 0.22 & 4.45 & 2.11 \\
\hline & & $\mathrm{F}(\mathrm{I})$ & 201 & 202 & 9.99 & 0.42 & 1.40 & 5.90 & 2.05 \\
\hline & & $\mathrm{L}$ & 147 & 146 & 7.99 & 1.23 & 1.35 & 4.99 & 2.01 \\
\hline \multirow[t]{6}{*}{ OS } & \multirow[t]{3}{*}{ bedding } & $\mathrm{Vt}$ & 199 & 200 & 5.12 & 0.15 & 0.49 & 4.05 & 2.19 \\
\hline & & $\mathrm{F}(\mathrm{I})$ & 210 & 211 & 8.14 & 0.35 & 0.39 & 3.99 & 2.10 \\
\hline & & $\mathrm{L}$ & - & - & - & - & - & - & - \\
\hline & \multirow[t]{3}{*}{ section } & $\mathrm{Vt}$ & 200 & 201 & 4.21 & 0.39 & 0.19 & 4.02 & 2.20 \\
\hline & & $\mathrm{F}(\mathrm{I})$ & 211 & 213 & 7.78 & 1.20 & 1.39 & 5.12 & 2.13 \\
\hline & & $\mathrm{L}$ & - & - & - & - & - & - & - \\
\hline \multirow[t]{6}{*}{$\mathrm{T}$} & \multirow[t]{3}{*}{ bedding } & $\mathrm{Vt}$ & 212 & 217 & 6.72 & 1.32 & 2.66 & 4.53 & 2.21 \\
\hline & & $\mathrm{F}(\mathrm{I})$ & 233 & 234 & 7.38 & 1.17 & 1.81 & 4.61 & 2.09 \\
\hline & & $\mathrm{L}$ & - & - & - & - & - & - & - \\
\hline & section & $\mathrm{Vt}$ & 232 & 226 & 4.70 & 0.03 & 0.57 & 4.21 & 2.19 \\
\hline & & $\mathrm{F}(\mathrm{I})$ & 236 & 249 & 9.26 & 1.79 & 2.38 & 3.44 & 2.07 \\
\hline & & $\mathrm{L}$ & - & - & - & - & - & - & - \\
\hline A & beddinge & $\mathrm{Vt}$ & 253 & 253 & 3.38 & 2.34 & 7.09 & 2.98 & 2.25 \\
\hline & & $\mathrm{F}(\mathrm{I})$ & 250 & 249 & 4.35 & 0.41 & 0.19 & 4.05 & 2.12 \\
\hline & & $\mathrm{L}$ & - & - & - & - & - & - & - \\
\hline & section & $\mathrm{Vt}$ & 249 & 248 & 4.07 & 0.02 & 0.55 & 4.01 & 2.25 \\
\hline & & $\mathrm{F}(\mathrm{I})$ & 251 & 250 & 4.89 & 0.96 & 0.27 & 3.51 & 2.13 \\
\hline & & $\mathrm{L}$ & - & - & - & - & - & - & - \\
\hline
\end{tabular}




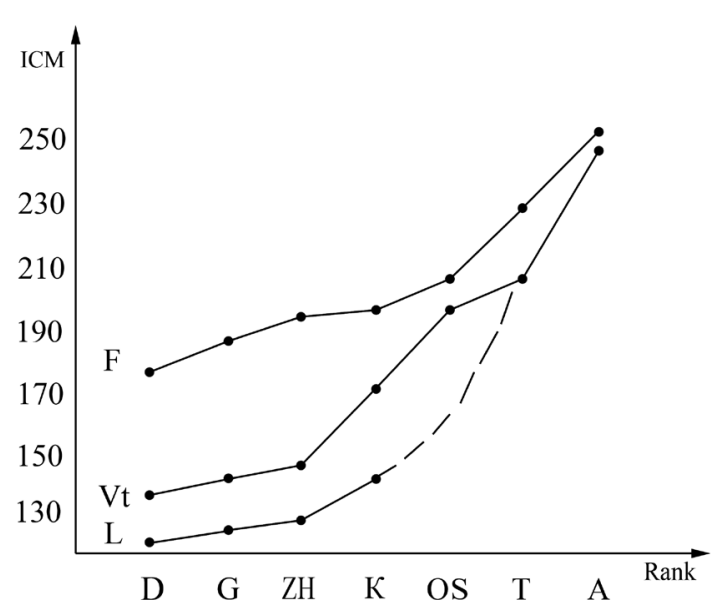

Fig. 6. The change in the intensity index of the gray color in a series of metamorphism for various macerals:

$F$-fusinite; Vt-vitrinite; L-liptinit

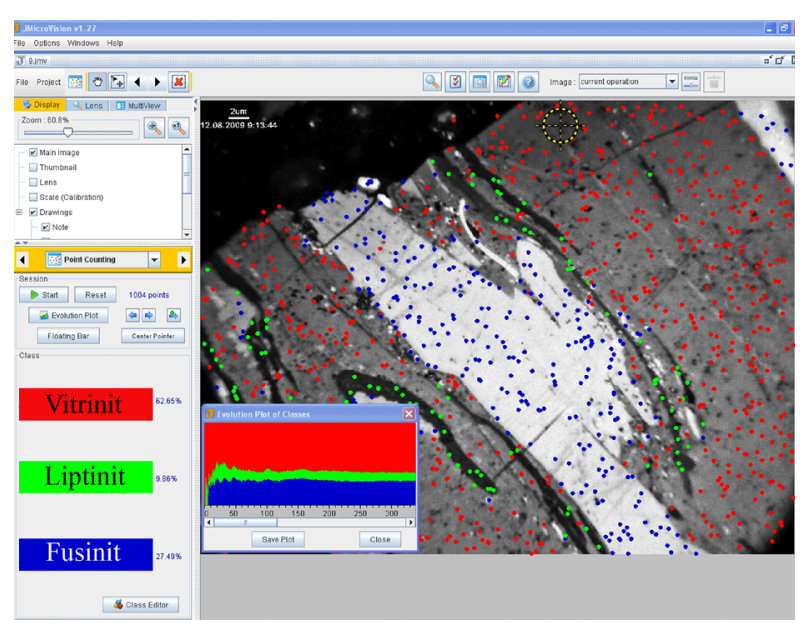

Fig. 7. Calculating the petrographic composition in the Jmicrovision software

- new indexes - entropy, kurtosis, skewness of the distribution of gray shade values reveal the heterogeneity of the gelified substance of coals and can characterize the recoverability of coals and petrographic composition nuances, in contrast to its gross calculation (both qualitatively and digitally);

- the method of digital processing of micro photo images allows recording data from the surface of a sample with a diameter of $0.4 \mu \mathrm{m}$, in contrast to $20 \mu \mathrm{m}$ when measuring the vitrinitere flectanceusing standard methods, which increases the reliability of measurements. The method does not require expensive equipment, it is easy to use;

- the values of ICM in the series of metamorphism grow for all microcomponents. In vitrinite and liptinite they are aligned in the field of OS-T ranks, in vitrinite and fusinite - in anthracite;

- the ICM index in the area (ICM. mean), although insignificantly, is always greater than the similar one recorded at the point (P. ICM);

- the ICM index by layering is always less than analogous one in the section;
- macerals of the liptinit group have the greatest heterogeneity;

- there is a tendency for the heterogeneity of the gelified substance to decrease with increasing the degree of metamorphism.

The proposed method can be used for practical application in order to assess the degree of metamorphism of coals, to assess the recoverability of coals and to calculate their maceral composition.

\section{References.}

1. ASTM D388-18a. Standard Classification of Coals by Rank. ASTM International. West Conshohocken. PA. (2018). Retrieved from www.astm.org.

2. ISO 11760:2018(en) Classification of coals (n.d.). Retrieved from https://www.iso.org/obp/ui/\#iso:std:iso: 11760:ed-2:v1:en.

3. SS 3472:2015 Bevey coal, stone and anthracite. Classification 01.08.2016. (2016). Retrieved from http:// document.ua/vugillja-bure-kamE28099jane-taantracit_-klasifikacija-nor29387.html.

4. Hackley, P. (2014). Standardization of vitrinite reflectance measurements in shale petroleum systems: how accurate are my Ro data? Online Journal for E\&P Geoscientists. AAPG Annual Convention and Exhibition. Houston. $T X$. Retrieved from http://www.searchanddiscovery.com/ abstracts/html/2014/90189ace/abstracts/1841915.htm.

5. American Society for Testing and Materials (ASTM). (2011). Standard test method for microscopical determination of the reflectance of vitrinite dispersed in sedimentary rocks: West Conshohocken. PA. ASTM International. Annual book of ASTM standards: Petroleum products. lubricants. and fossil fuels; Gaseous fuels; coal and coke, 5(5.06. D7708-11), 823-830. DOI: 10.1520/D7708-11.

6. Jennifer M.K. O'Keefe, Achim Bechtel, Kimon Christanis, \& Shifeng Dai. (2013). On the fundamental difference between coal rank and coal type. International Journal of Coal Geology, 118, 58-87.

7. ScopePhotoImageSoftware (n.d.). Retrieved from http://labx.narod.ru/documents/scope_photo_image_ software.html.

8. Bezruchko, K.A., \& Baranovskiy, V.I. (2014). Marks of gas-generation processes in Donbas coal. Coal of Ukraine, 11, 31-33.

9. Bezruchko, K., \& Matrofailo, M. (2014). Formation dynamics of coal seams morphostructure of the deepseated horizons of the L'viv-Volyn' basin. Progressive Technologies of Coal. Coalbad Methane. Ores Mining. London: Taylor \& Francis Group. 201-207.

10. Jmicrovisionsoftware (n.d.). Retrieved from https:// www.jmicrovision.com/. html.

11. ImageJsoftware (n.d.). Retrieved from //rsb.info. nih.gov/ij/. html.

12. NAFE software (n.d.). Retrieved from http://www. zam.fme.vutbr.cz/ druck/Nafe/Index.htm.

\section{Новий спосіб визначення ступеня метаморфізму вугілля}

\section{К. А. Безручко, Л. І. Пимоненко, О. К. Балалаєв, В. І. Барановський}

ISSN 2071-2227, Naukovyi Visnyk NHU, 2019, № 3 
Інститут геотехнічної механіки імені М. С. Полякова Національної академії наук України, м. Дніпро, Україна, e-mail: gvrvg@meta.ua

Мета. Розробка та апробація нового способу визначення ступеню метаморфізму вугілля за показником інтенсивності відтінків мацералів мікрофотозображень штуфів-аншліфів вугільних препаратів.

Методика. Оптична спектроскопія з використанням відеоптичного комплексу: МБІ - 11, НВ 2003 наступною цифровою комп'ютерною обробкою (програмне забезпечення Scopephoto) мікрофотозображень препаратів вугільної речовини по штуфам-аншліфам.

Результати. Запропоновано новий спосіб визначення ступеню метаморфізму вугільної речовини, суть якого полягає у використанні оптичної мікроскопії штуфів-аншліфів зразків вугілля з наступною цифровою обробкою отриманих даних. Метод апробований на пробах вугілля різних марок - від довгополуменевих до антрацитів. Для характеристики ступеню метаморфізму вугілля застосовано новий показник інтенсивності відтінків сірого кольору мацералів на фотозображеннях штуфів-аншліфів вугільних препаратів під мікроскопом. Показана кореляція запропонованого показника із класичним показником ступеню метаморфізму вугілля - відбивною здатністю вітриніту.

Наукова новизна. Уперше для характеристики ступеню метаморфізму вугілля застосована цифрова обробка фотозображень штуфів-аншліфів зразків вугілля з використанням нового показника інтенсивності відтінків мацералів.

Практична значимість. Запропонований метод може використовуватися для практичного застосування з метою оцінки ступеню метаморфізму вугілля. Метод відрізняється оперативністю та простотою від широковживаного натепер способу визначення ступеню метаморфізму вугілля за відбивною здатністю вітриніту. Спосіб також може бути застосований для оцінки відновлюваності вугілля й підрахунку його мацерального складу.

Ключові слова: вугілля, метаморфізм, оптична мікроскопія, відтінки сірого кольору мацералів

\section{Новый способ определения степени метаморфизма углей}

\author{
К. А. Безручко, Л. И. Пимоненко, А. К. Балалаев, \\ В.И. Барановский
}

Институт геотехнической механики имени Н.С. Полякова Национальной академии наук Украины, г. Днепр, Украина, e-mail: gvrvg@meta.ua

Цель. Разработка и апробирование нового способа определения степени метаморфизма углей по показателю интенсивности оттенков серого цвета мацералов микрофотоизображений штуфов-аншлифов угольных препаратов.

Методика. Оптическая спектроскопия с использованием видеоптического комплекса: МБИ11, НВ 200 с последующей цифровой компьютерной обработкой (программное обеспечение Scopephoto) микрофотоизображений препаратов угольного вещества по штуфам-аншлифам.

Результаты. Предложен новый способ определения степени метаморфизма угольного вещества, суть которого заключается в использовании оптической микроскопии штуфов-аншлифов образцов углей с последующей цифровой обработкой полученных данных. Метод апробирован на пробах углей различных марок - от длиннопламенных до антрацитов. Для характеристики степени метаморфизма углей применен новый показатель интенсивности оттенков серого цвета мацералов на фотоизображениях штуфов-аншлифов угольных препаратов под микроскопом. Показана корреляция предложенного показателя с классическим показателем степени метаморфизма углей - отражательной способностью витринита.

Научная новизна. Впервые для характеристики степени метаморфизма углей применена цифровая обработка фотоизображений штуфов-аншлифов образцов углей с использованием нового показателя интенсивности оттенков серого цвета мацералов.

Практическая значимость. Предложенный метод может использоваться для практического применения с целью оценки степени метаморфизма углей. Метод отличается оперативностью и простотой от широкоприменяемого в настоящее время метода определения степени метаморфизма углей по отражательной способности витринита. Метод также может быть применен для оценки восстановленности углей и подсчета их мацерального состава.

Ключевые слова: уголь, метаморфизм, оптическая микроскопия, оттенки серого ивета мацералов

Рекомендовано до публікації докт. геол.-мін. наук В.В.Лукіновим. Дата надходження рукопису 19.12.17. 